\title{
A COMPARISON OF GROUND AND CANOPY LEAF LITTER ANTS (HYMENOPTERA: FORMICIDAE) IN A NEOTROPICAL MONTANE FOREST
}

\author{
By John T. Longino' and Nalini M. NADKarni ${ }^{2}$ \\ Department of Biological Sciences, University of California, \\ Santa Barbara, California 93106
}

\begin{abstract}
INTRODUCTION
The most conspicuous habitat discontinuity in forests is that between ground and canopy. These two microhabitats support strikingly distinct biotic communities. Among ants, species that nest in the ground or in leaf litter are typically in different genera from arboreal species, which nest in or on plants, the two groups exhibiting divergent morphologies which reflect their respective nesting habits (Wheeler 1910, Wilson 1959). The arboreal microhabitat is clearly three-dimensional (Richards 1983) and has inspired investigations of vertical stratification among arboreal taxa, including birds (Pearson 1971, Terborgh 1980), mammals (Harrison 1962), and flying insects (Bates 1944, Sutton et al. 1983). Arboreal ants exhibit vertical stratification, some species being restricted to high canopy, others to forest understory (Wilson 1959).

The ground microhabitat is generally considered to be a twodimensional layer of soil and leaf litter, home to an ant community very distinct from the arboreal community. In many tropical forests, however, large amounts of leaf litter and other organic material accumulate in the canopy, imparting a three-dimensional structure to dead organic matter. The "crown humus" (Jenik 1973) consists of litter intercepted from overstory tree branches and from abscissed epiphyte tissues. Accumulations of crown humus are particularly pronounced in montane forests (Nadkarni 1984; Pócs 1976, 1980).
\end{abstract}

\footnotetext{
'Present address: Allyn Museum of Entomology, 3621 Bay Shore Road, Sarasota, Florida 34234 USA

2Present Address: The Marie Selby Botanical Gardens, 811 South Palm Avenue, Sarasota, Florida 34236 USA

*Manuscript received by the editor January 25, 1990.
} 
Mats of mosses, filmy ferns, and other epiphytes grow from a thick layer of dead organic matter that blankets trees. The layer covers inner branches and trunks, and is frequently contiguous with the organic layer on the ground.

Given a three-dimensional distribution of dead organic matter, do litter-inhabiting ants exhibit vertical stratification also? Is crown humus inhabited by ant genera which are typical litter-inhabitants? If so, are the same species found in both forest-floor leaf litter and crown humus, or are there distinct microhabitat specialists inhabiting canopy humus? We addressed these questions by contrasting the ant communities inhabiting ground litter and crown humus in a montane forest in Costa Rica.

\section{Materials AND Methods}

Research was conducted in the Monteverde Cloud Forest Reserve and adjacent forest, located in west-central Costa Rica $\left(10^{\circ} 18^{\prime} \mathrm{N}\right.$, $84^{\circ} 48^{\prime} \mathrm{W}$ ), at $1550 \mathrm{~m}$ elevation. The Reserve protects a portion of the ridge crest of the Cordillera de Tilarán, which divides the wet forests of the Atlantic slopes from the dry forest and pastures of the Pacific slopes (Lawton \& Dryer 1980). The climate of the Reserve is strongly influenced by the northeast trade winds, which carry considerable amounts of mist and fog, especially during the dry season (November to March). Rainfall near the Reserve averages $2450 \mathrm{~mm} / \mathrm{yr}$ (Lawton \& Campbell 1984). Actual precipitation is no doubt much higher than that recorded in standard rain gauges due to the input of mist.

The cloud forest is nearly always cool and wet, and canopy branches are cloaked in epiphyte mats consisting of live epiphytes and the underlying dead organic matter. The estimated standing crop of live and dead canopy organic matter is $\mathbf{4 7 0 0}$ metric tons/ ha, which falls within the range of other tropical cloud forests $(\mathrm{Nad}-$ karni 1984). On the large size classes of trees $(>80 \mathrm{~cm} \mathrm{dbh})$ epiphyte mats on interior branches are fairly uniform; major differences in epiphyte loads between host trees that have been noted in other forest types (e.g., Went 1940) are not apparent in this forest (pers. obs.). We selected sample trees of the largest size class and epiphyte loads. All sample trees were of genera common at the study site: Clusia, Didymopanax, Quercus, Pouteria, and Ficus. 
The ant community was sampled using Winkler litter-sifting and arthropod extraction devices (Ward 1987). Sifting litter is a very effective way of surveying litter fauna because of the large quantity of litter that is processed. Bulk litter is gathered by hand, placed in a sifter, and shaken. Soil invertebrates and other particulate matter fall through the $9 \mathrm{~mm}$ mesh sieve into a collecting bag. Sifted litter is transferred to several flat mesh sacks which are suspended within an outer cloth bag, hanging much like combs hang within a bee hive. The bag closes at the top and tapers at the bottom to a cup of alcohol. The bag with enclosed sifted litter is hung in a sheltered place and left to air-dry for three days. As the litter dries, the soil invertebrates work their way out of the mesh sacks and drop to the alcohol.

Twelve paired samples of litter were taken from the Monteverde cloud forest, 8 in June-July 1984, and 4 in December 1987. One sample of each pair was taken from the inner crown regions of a canopy tree and the other from the ground immediately below. Canopy height varied from $5 \mathrm{~m}$ in exposed windward forest to $30 \mathrm{~m}$ in leeward cove forest. To obtain samples, we climbed into the canopy of each tree (Perry 1978) and sifted all leaf litter within our reach until we had between 2 and 81 sifted litter. We gathered forest floor litter from directly below the same tree, until a similar quantity was obtained. We air-dried each pair of samples in two separate hanging bags in the field laboratory. In the Monteverde cloud forest, an average of 171 of bulk litter produced one 1 sifted litter. The 24 separate samples yielded approximately 1501 sifted litter total, which represented over 25001 bulk litter.

All ant workers from the samples were counted and either identified to species or assigned to morphospecies. Only adult workers were counted, owing to the uncertainty of associating queens and males with conspecific workers. The poor state of the taxonomy of nearly all the genera involved in this study required the extensive use of morphospecies. These morphospecies have been developed within the context of a faunal survey of Costa Rican ants, and are based on many collections in addition to those in this report. Identified voucher material from this study was deposited in the Los Angeles County Museum of Natural History and the research collection of $\mathbf{J}$. Longino. A synoptic collection of Costa Rican ants, including a general collection of Monteverde ants, is currently being developed at the Instituto Nacional de Biodiversidad in Costa Rica. 


\section{RESUlTS}

Total samples of 2931 and 1067 individual ants were obtained from the ground and the canopy, respectively. These were distributed in 53 ant species in 25 genera (Appendix 1). Three subfamilies of ants were represented: Myrmicinae dominated the samples, Ponerinae and Formicinae were less abundant. Dolichoderinae, a large subfamily with abundant arboreal forms in the neotropics, was conspicuously absent.

Most of the ants encountered, in both canopy and ground samples, were in genera which typically inhabit leaf litter. The exceptions were a few individuals in arboreal genera, six Myrmelachista workers and 11 Camponotus workers, which were found in canopy samples. These arboreal ants are common stem-nesting ants in the Monteverde canopy (pers. obs.), and are excluded from subsequent analyses. The remaining 1050 individuals from canopy samples were in typical litter-inhabiting genera.

The canopy litter ant community was depauperate relative to the ground community. Canopy samples contained $5.8 \pm 1.5$ species (95\% confidence intervals, $\mathrm{n}=12$ ); ground samples contained 16.6 \pm 4.3 species. The cumulative number of species in all 12 samples in each microhabitat was 21 in the canopy, 48 on the ground (Appendix I). The reduced number of species obtained from the canopy could have been the result of sampling artifact, given that the total number of ants obtained from the canopy was less than half the number from the ground. To account for sample size differences, we simulated repeated subsampling from the observed ground sample. 1050 ants were randomly sampled, without replacement, from the 2931 ground ants, and the number of species counted. Cumulative number of species in the simulated subsampling was $39.4 \pm 0.44$ (95\% confidence interval, $\mathrm{n}=100$ ), still much larger than the observed 21 species from the canopy samples.

Dominance-diversity curves (sensu Whittaker 1975) were plotted to discern major patterns in community structure (Figure 1). Relative abundance of each species was based on the number of individuals in all 12 samples for a given microhabitat. The two communities were roughly similar in the relative abundances of the 8 most abundant species. The ground community had a much larger number of less abundant species, indicated by the longer tail in Figure 1. A dominance diversity curve was generated from the 


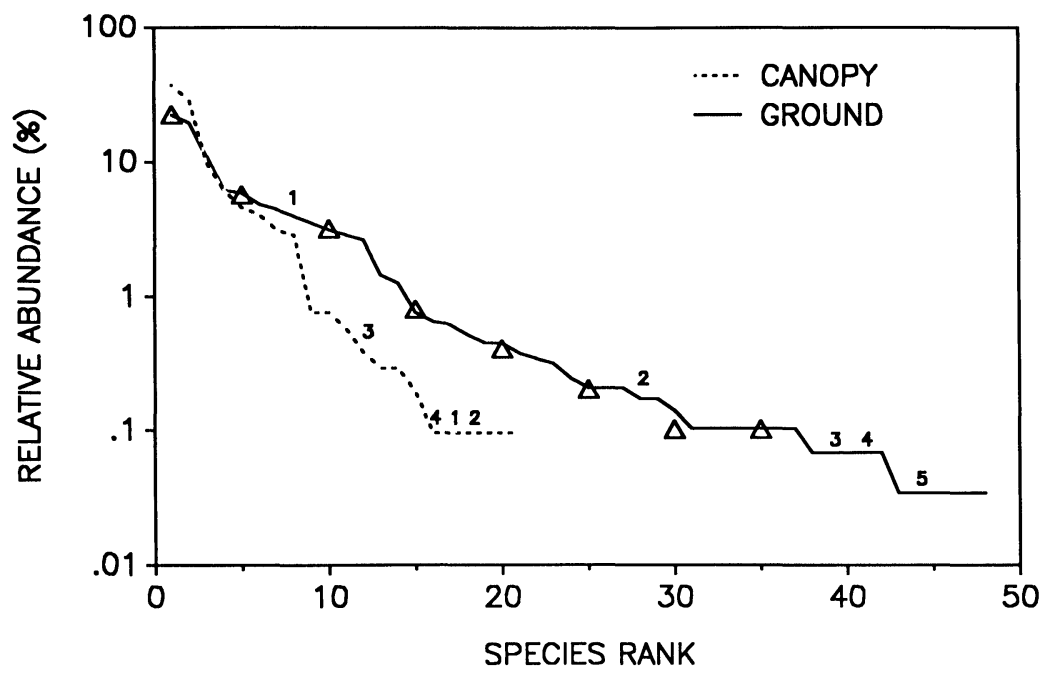

Figure 1. Dominance-diversity curves for canopy and ground ant communities. Relative abundance is from total number of individuals in all 12 samples. Open triangles are from simulated subsampling of the ground community, equalizing sample sizes for ground and canopy. Numbers above curves are the rank of a given species in the alternate microhabitat, for the 5 most abundant species in each microhabitat (the fifth most abundant species on the ground did not occur in the canopy). Note that species with high relative abundance in one microhabitat have low relative abundance in the other.

results of the random subsampling of ground ants described above. It was nearly identical to the ground curve based on the full data set. The difference in curves between canopy and ground is clearly not an artifact of the smaller sample size from the canopy.

The litter ant community in the canopy was taxonomically distinct from the ground community. It was not simply a restricted subset of the ground community that also foraged in the canopy. Except for one species (Solenopsis JTL-01), the most abundant species in one microhabitat were among the rarest species in the other (Figure 1). This pattern held not only for relative abundance in terms of number of individuals, but also for frequency of occurrence in samples (Figure 2). Species that were frequently found in canopy samples were infrequently found on the ground, and vice versa. 
Stenamma JTL-02

Solenopsis JTL-01

Pheidole innupta

Solenopsis JTL-02

Hypoponera JTL-03

Brachymyrmex JTL-02

Pheidole JTL-24

Pheidole JTL-35

Discothyrea horni

Solenopsis JTL-04

Hypoponera JTL-01

Adelomyrmex tristani

Solenopsis JTL-03

Hypoponera JTL-02

Gnamptogenys strigata

Neostruma brevicornis

Solenopsis JTL-01

Eurhopalothrix JTL-01

Paratrechina JTL-04

Pheidole JTL-11

Neostruma myllorhapha

Stenamma JTL-01

NUMBER OF SAMPLES

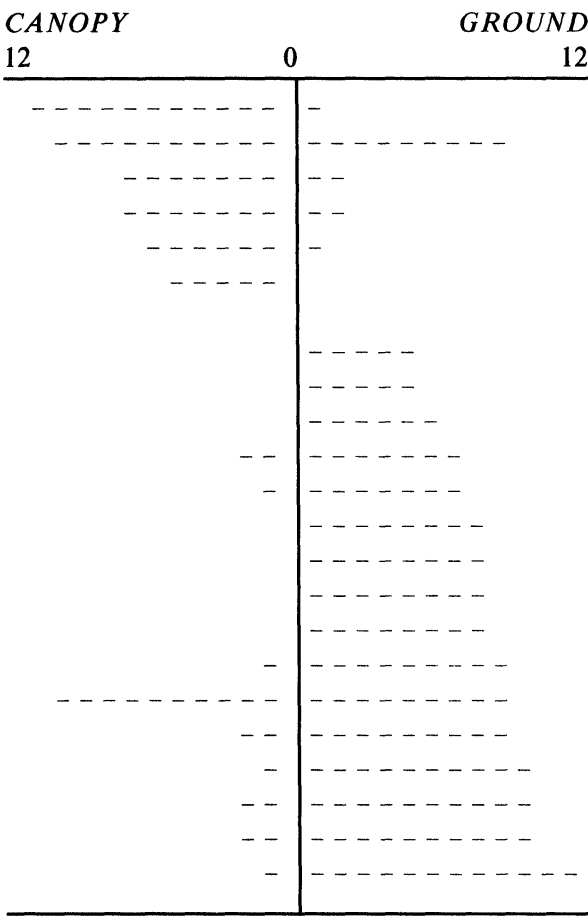

Figure 2. Frequency of occurrence of ant species in litter samples. Species occurring in at least 4 litter samples from the same microhabitat are shown.

Ants in the three genera Solenopsis, Pheidole, and Stenamma comprised $53 \%$ of the ants in the ground samples and $85 \%$ of the ants in the canopy samples. Below we describe in more detail the striking phenomenon of canopy versus ground specialization by congeners in this trio of predominant ant genera (Table 1).

Solenopsis subgenus Diplorhoptrum is a group of $1-2 \mathrm{~mm}$ long myrmicines that are common elements of wet forest litter fauna throughout the neotropics. Solenopsis JTL-01 and Solenopsis JTL02 were the two most abundant species of ants in the Monteverde canopy. General collecting confirmed their ubiquity and canopy nesting habits. These two species formed massive populations under epiphyte mats. In tree crowns where these species occurred, pulling up a mat of epiphytes and organic matter exposed a network of 
Table 1. Microhabitat specialization by predominant leaf litter ant species. Numbers of individuals are summed across 12 samples.

SPECIES

Solenopsis JTL-01

Solenopsis JTL-02

Solenopsis JTL-03

Stenamma JTL-01

Stenamma JTL-02

Pheidole JTL-10

Pheidole innupta

galleries at the interface of tree bark and organic matter, with scattered colony fragments containing knots of workers, brood piles, and one or more dealate queens. Solenopsis JTL-01 was the only species found commonly in both microhabitats, although it was more abundant in the canopy. In contrast, a third species, Solenopsis JTL-03, was a strict ground inhabiting species (Table 1).

Stenamma is a predominantly holarctic genus of $2-4 \mathrm{~mm}$ long myrmicines that form small cryptic colonies and forage in leaf litter. Their distribution extends into Central America, mainly in the highlands. In Monteverde, Stenamma JTL-02 was clearly a canopy specialist, while Stenamma JTL-01 was a ground inhabitant (Table 1). General collecting in Monteverde and other highland sites in Costa Rica has revealed a third species, Stenamma JTL-3, that nests under moss mats in the forest understory. Workers of this species did not occur in our litter samples from the ground or canopy, suggesting a 3-tiered vertical stratification in this genus.

Pheidole is a taxonomically and structurally diverse genus distributed worldwide. The Monteverde samples contained nine species of Pheidole, one of which was a very abundant species on the ground, and one of which was predominant in the canopy. Results from general collections concur with those from litter samples. Pheidole innupta was commonly found nesting in the canopy, but never on the ground. Pheidole JTL-11 nests were always on the ground, never in the canopy. The remaining species were infrequently encountered and their status with respect to vertical stratification is unknown.

Canopy litter ants were morphologically very similar to groundnesting species. There were no obvious morphological correlates with canopy specialization. 


\section{Discussion}

In the Monteverde cloud forest, species of typical ground-nesting ant genera were found inhabiting accumulated leaf litter in the forest canopy. Since the same genera were typically found in both ground and canopy samples, we expected to find only partial vertical stratification, in which a subset of ground ants extended their ranges into the canopy. Instead, we found strong stratification of ground and canopy communities, with canopy specialists and ground specialists within the same ant genera, and little overlap in species composition between the two microhabitats.

In a study of niche partitioning in a Maryland ant community, Lynch (1981) found that stratification along "vertical microhabitat" contributed significantly to local diversity. Vertical microhabitat in Lynch's study was two substrate types, leaf litter and low vegetation. Our study in Monteverde confirmed the primary importance of substrate type to the structure of ant communities. We found ground nesting genera of ants inhabiting leaf litter $20 \mathrm{~m}$ above the forest floor.

Vertical stratification at the species level has been well documented for some arboreal taxa (e.g., Terborgh 1980, Sutton et al. 1983). This is the first report of vertical stratification in litter inhabitants. Vertical stratification in tropical forests is not surprising given the great environmental differences in the vegetation column. The upper canopy of lowland forests is known to differ from the understory in microclimate, being more insolated and experiencing higher temperature and wind (Cachan 1963, Yoda 1974, Chazdon \& Fetcher 1984). Although not as pronounced, these differences also occur in montane forest; canopy soil is warmer and drier during the dry season (Nadkarni, unpub. dat.). In addition to microclimatic differences, canopy soil is very different from ground soil both chemically and physically (Nadkarni \& Vance, unpub. dat.). Thus, litter substrates which appear similar may be very different to invertebrate inhabitants with respect to microhabitat characteristics that affect their distribution. For example, litter invertebrates are known to respond strongly to litter moisture content (Levings et al. 1984).

Vertical stratification of litter organisms may be more prominent in tropical montane forests than in lowland forests. Epiphyte biomass is estimated as three orders of magnitude higher in montane forests than in lowland humid forests (Golley et al. 1971; Nadkarni 
1984). Using fogging techniques designed to sample canopy arthropods (Erwin 1983), ants obtained from a lowland Peruvian site contained almost no members of typically ground-nesting genera (Wilson 1987). Vertical stratification of litter ants in the lowlands should not be ruled out, however. Adis et al. (1984) question the efficacy of canopy fogging for obtaining litter-inhabiting arthropods, and closer taxonomic scrutiny could be given to organisms inhabiting the root mats of large epiphyte clumps in lowland forest.

This study has demonstrated previously unrecognized patterns of tropical ant distribution. The ideas presented here should be further investigated in three areas. First, a better understanding of the taxonomy of the species involved is critical. Comparisons of a species' microhabitat specialization in different parts of its range and under different environmental conditions cannot be investigated without some prior knowledge of species level taxonomy. Second, the phenomenon of canopy litter specialization needs to be substantiated by additional sampling over a broader geographic range. Third, proximate causes of vertical stratification should be investigated. Vertical stratification could be the result of searching behavior and patterns of settlement of founding queens, and/or by competitive relationships between established colonies.

Vertical stratification of arboreal organisms contributes to the great diversity of tropical forests. Vertical stratification of leaf litter organisms is a previously unrecognized source of tropical diversity, especially in tropical montane forests.

\section{SUMMARY}

Vertical microhabitat stratification by leaf litter ants was investigated in the Monteverde cloud forest, Costa Rica. Paired samples of ants were taken from leaf litter on the ground and from litter and humus that accumulates under epiphyte mats in the forest canopy. The genera found in the canopy were typical litter inhabitants, and were a subset of those found on the ground. At the species level, the ant communities in the two microhabitats were distinct. Predominant species in the canopy were very rarely found on the ground and vice versa. Thus, vertical stratification is exhibited by litterinhabiting ants. 


\section{ACKNOWLEDGMENTS}

We thank the personnel of the Monteverde Cloud Forest Reserve, the Tropical Science Center, and the people of Monteverde for their support. John Endler and Sally Hollbrook made helpful comments on a draft of this manuscript. Financial support was provided by National Geographic grants 2899-84 and 2900-84, the University of California Academic Senate Committee for Research, a grant from the Whitehall Foundation, and NSF grant DEB 86-14935.

APPENDIX 1: Species of ants from canopy and ground leaf litter samples. For each species and each microhabitat, total number of individuals is shown, followed by frequency of occurrence in the 12 samples.

GROUND CANOPY

Subfamily Ponerinae

Amblyopone orizabana

Gnamptogenys interrupta

Gnamptogenys strigata

Proceratium micrommatum

Discothyrea horni

Pachycondyla aenescens

Pachycondyla JTL-5 (cf. ferruginea)

Cryptopone guatemalensis (?)

Hypoponera JTL-01

Hypoponera JTL-02

Hypoponera JTL-03

Hypoponera JTL-05

Simopelta paeminosa

$\begin{array}{rlll}6 & 2 & - & - \\ 3 & 1 & - & - \\ 42 & 8 & - & - \\ 3 & 3 & - & - \\ 15 & 6 & - & - \\ 2 & 2 & - & - \\ 3 & 1 & - & - \\ 3 & 2 & - & - \\ 18 & 7 & 2 & 1 \\ 77 & 8 & - & - \\ 1 & 1 & 30 & 6 \\ 7 & 1 & - & - \\ 19 & 1 & 8 & 1\end{array}$

Subfamily Myrmicinae

Stenamma expolitum

Stenamma felixi

Stenamma JTL-01 (cf. schmidti)

Stenamma JTL-02 (cf. schmidti)

Stenamma JTL-04

Pheidole annectens

Pheidole innupta

Pheidole JTL-11

Pheidole JTL-16

Pheidole JTL-18

Pheidole JTL-24

Pheidole JTL-35

Pheidole JTL-50

Pheidole JTL-58

Solenopsis JTL-01

$\begin{array}{rrrrr}5 & 3 & - & - \\ 3 & 3 & - & - \\ 655 & 12 & 1 & 1 \\ 1 & 1 & 48 & 11 \\ 1 & 1 & - & - \\ - & - & 1 & 1 \\ 2 & 2 & 102 & 7 \\ 323 & 10 & 4 & 2 \\ 22 & 3 & 1 & 1 \\ 6 & 2 & - & - \\ 171 & 5 & - & - \\ 37 & 5 & - & - \\ 6 & 2 & 8 & 2 \\ 1 & 1 & - & - \\ 118 & 9 & 387 & 10\end{array}$


APPENDIX 1: (continued)

Solenopsis JTL-02

Solenopsis JTL-03

Solenopsis JTL-04

Solenopsis JTL-14

Adelomyrmex tristani

Wasmannia auropunctata

Eurhopalothrix JTL-01

Octostruma rugiferoides

Octostruma wheeleri

Glamyromyrmex JTL-01

Neostruma brevicornis

Neostruma myllorhapha

Strumigenys biolleyi

Strumigenys JTL-02

Strumigenys JTL-05

Smithistruma JTL-01 (cf. schulzi)

Smithistruma probatrix

Cyphomyrmex JTL-01 (cf. salvini)

\begin{tabular}{rrrr}
\multicolumn{3}{c}{ GROUND } & \multicolumn{2}{c}{ CANOPY } \\
5 & 2 & 302 & 7 \\
105 & 8 & - & - \\
84 & 7 & 43 & 2 \\
1 & 1 & - & - \\
131 & 8 & - & - \\
- & - & 1 & 1 \\
92 & 9 & 3 & 2 \\
3 & 2 & - & - \\
2 & 1 & - & - \\
13 & 1 & - & - \\
179 & 9 & 1 & 1 \\
142 & 10 & 6 & 2 \\
10 & 4 & - & - \\
2 & 1 & - & - \\
11 & 3 & - & - \\
4 & 3 & 3 & 2 \\
1 & 1 & - & - \\
9 & 3 & - & -
\end{tabular}

Subfamily Formicinae

Acropyga JTL-01

Brachymyrmex JTL-01

Brachymyrmex JTL-02

Brachymyrmex JTL-03

$\begin{array}{rrrr}3 & 1 & - & - \\ 13 & 2 & - & - \\ - & - & 33 & 5 \\ 2 & 1 & 65 & 4 \\ 569 & 10 & 1 & 1\end{array}$

Paratrechina JTL-04

\section{Literature Cited}

Adis, J., Lubin, Y. D. And Montgomery, G. G.

1984. Arthropods from the canopy of inundated and terra firme forests near Manaus, Brazil, with critical considerations on the pyrethrum-fogging technique. Studies on Neotropical Fauna and Environment 19: 223-236.

BATES, $M$.

1944. Observations on the distribution of mosquitos in a tropical forest. Ecology 25: 159-170.

CACHaN, P.

1963. Signification écologique des variations microclimatiques verticales dans la forêt sempervirente de Basse Cote d'Ivoire. Annales Faculté Sciences Dakar 8: 89-155.

Chazdon, R. ANd Fetcher, N.

1984. Photosynthetic light environments in a lowland tropical rainforest in Costa Rica. Jour. Ecol. 72: 553-564. 
ERwin, T. L.

1983. Beetles and other insects of tropical forest canopies at Manaus, Brazil, sampled by insecticidal fogging. Tropical Rain Forest: Ecology and Management, Special Publication Number 2 of The British Ecological Society (Ed. by S. L. Sutton, T. C. Whitmore \& A. C. Chadwick), pp. 59-75. Blackwell Scientific Publications, Oxford.

Golley, F., McGinnis, J. And Clements, R.

1971. La biomasa y la estructura de algunos bosques de Darien, Panama. Turrialba 21: 189-196.

HARRISON, J. L.

1962. The distribution of feeding habits among animals in a tropical rain forest. Jour. Animal Ecol. 31: 53-63.

JENIK, J.

1973. Root systems of tropical trees. 8. stilt roots and allied adaptations. Preslia 45: 250-264.

LaWton, R. AND CAMPBell, J.

1984. Climate and vegetation of a neotropical montane forest (abstract). Bull. Ecol. Soc. Amer. 65: 59.

LAWTON, R. AND DRYer, V.

1980. The vegetation of the Monteverde Cloud Forest Reserve. Brenesia 18: 101-116.

LEVINGS, S. C. AND Windsor, D. M.

1984. Litter moisture content as a determinant of litter arthropod distribution and abundance during the dry season on Barro Colorado Island, Panama. Biotropica 16: 125-131.

LYNCH, J. F.

1981. Seasonal, successional, and vertical segregation in a Maryland ant community. Oikos 37: 183-198.

NADKARNI, N.

1984. Epiphyte biomass and nutrient capital of a neotropical elfin forest. Biotropica 16: 249-256.

Pearson, D.

1971. Vertical stratification of birds in a tropical dry forest. Condor: 73: 46-55.

Perry, D.

1978. A method of access into the crowns of emergent and canopy trees. Biotropica 10: 155-157.

Pócs, T.

1976. Bioclimatic studies in the Uluguru Mountains (Tanzania, East Africa). II. correlations between orography, climate and vegetation. Acta Botanica Academiae Scientiarum Hungaricae 22: 163-183.

Pócs, T.

1980. The epiphytic biomass and its effect on the water balance of two rainforest types in the Uluguru Mountains (Tanzania, East Africa). Acta Botanica Academiae Scientiarum Hungaricae 26: 143-167. 
RichaRDS, P. W.

1983. The three-dimensional structure of tropical rainforest. Tropical Rain Forest: Ecology and Management, Special Publication Number 2 of The British Ecological Society (Ed. by S. L. Sutton, T. C. Whitmore \& A. C. Chadwick), pp. 3-10. Blackwell Scientific Publications, Oxford.

Sutron, S. L., Ash, C. P. J. And Grundy, A.

1983. The vertical distribution of flying insects in lowland rainforests of Panama, Papua New Guinea and Brunei. Zool. Jour. Lin. Soc. 78: 287-297.

TERBORGH, J.

1980. Vertical stratification of a neotropical forest bird community. Proceedings of the 17th International Ornithological Congress, pp. 1005-1012.

WARD, P. S.

1987. Distribution of the introduced Argentine ant (Iridomyrmex humilis) in natural habitats of the lower Sacramento Valley and its effects on the indigenous ant fauna. Hilgardia 55: 1-16.

WENT, F.

1940. Soziologie der Epiphyten eines tropischen Urwaldes. Annales de jardin botanique de Buitzenborg 50: 1-98.

WHEELER, W. M.

1910. Ants: Their Structure, Development and Behavior. Columbia University Press, New York.

WhITTAKER, R. H.

1975. Communities and Ecosystems, 2nd Edition. Macmillan Publishing, New York.

WILSON, E. O.

1959. Some ecological characteristics of ants in New Guinea rain forest. Ecology 40: 437-447.

WILSON, E. O.

1987. The arboreal ant fauna of Peruvian Amazon forests: a first assessment. Biotropica 19: 245-251.

YodA, $\mathrm{K}$.

1974. Three-dimensional distribution of light intensity in a tropical rain forest of West Malaysia. Japanese Jour. Ecol. 24: 247-254. 

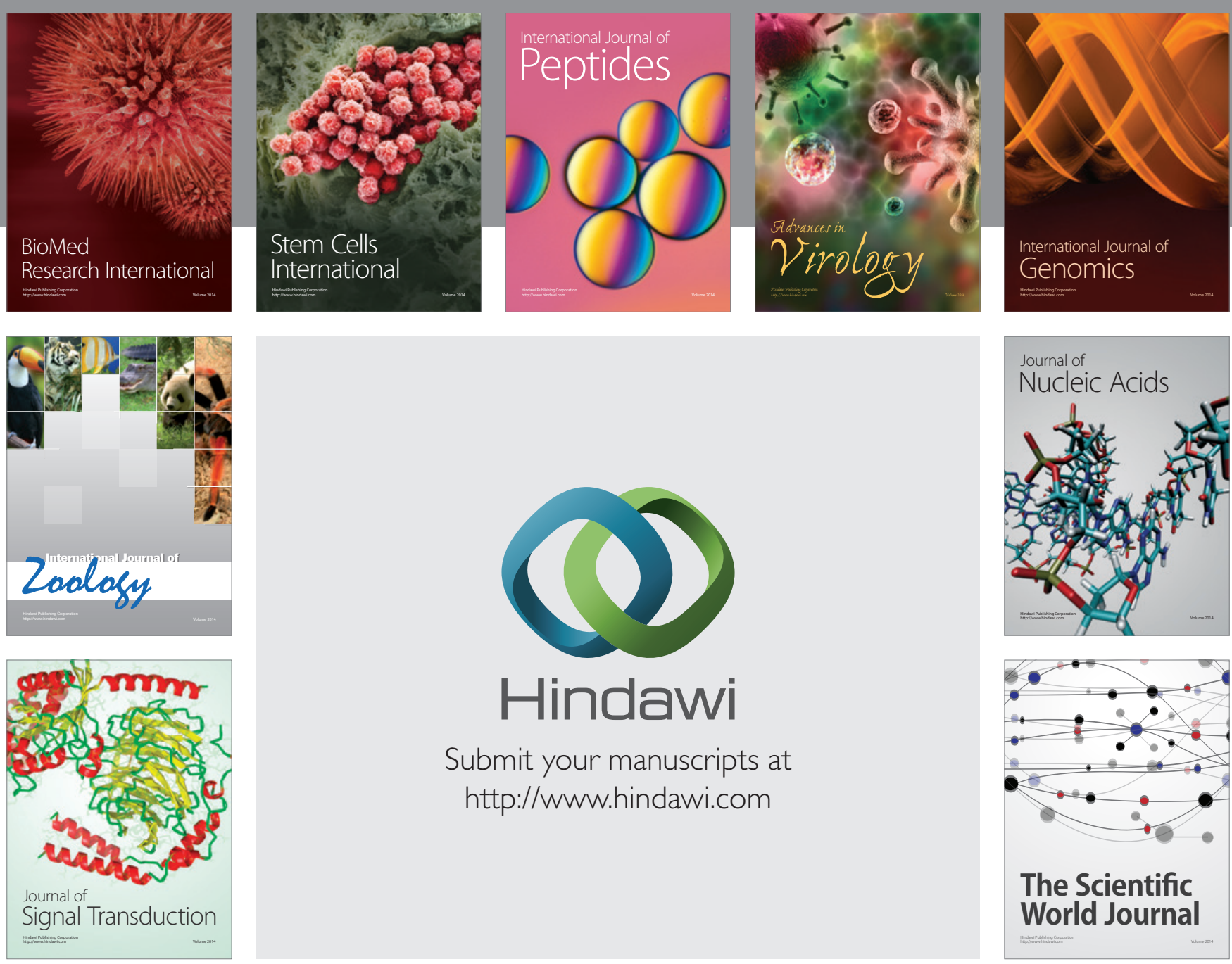

Submit your manuscripts at

http://www.hindawi.com
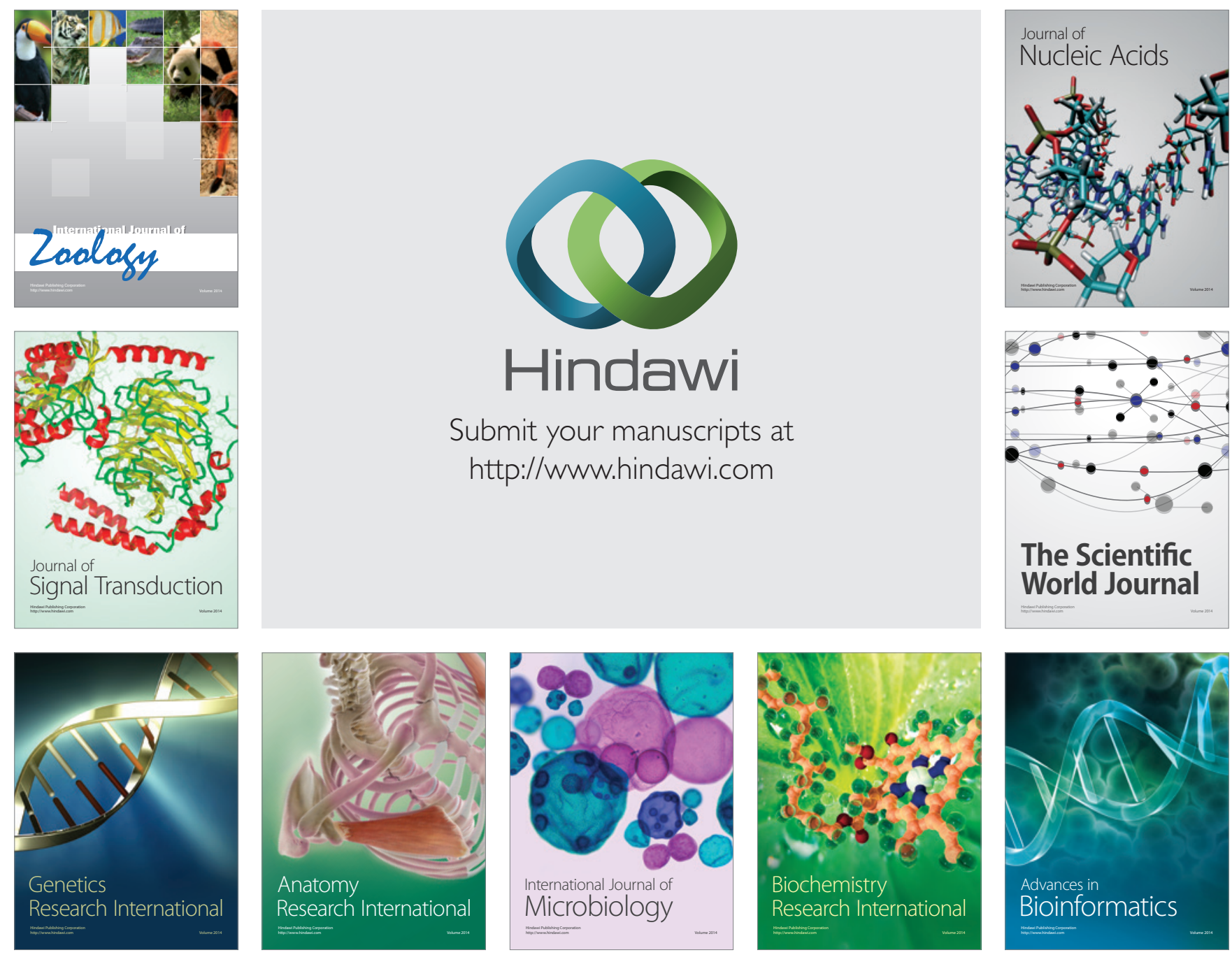

The Scientific World Journal
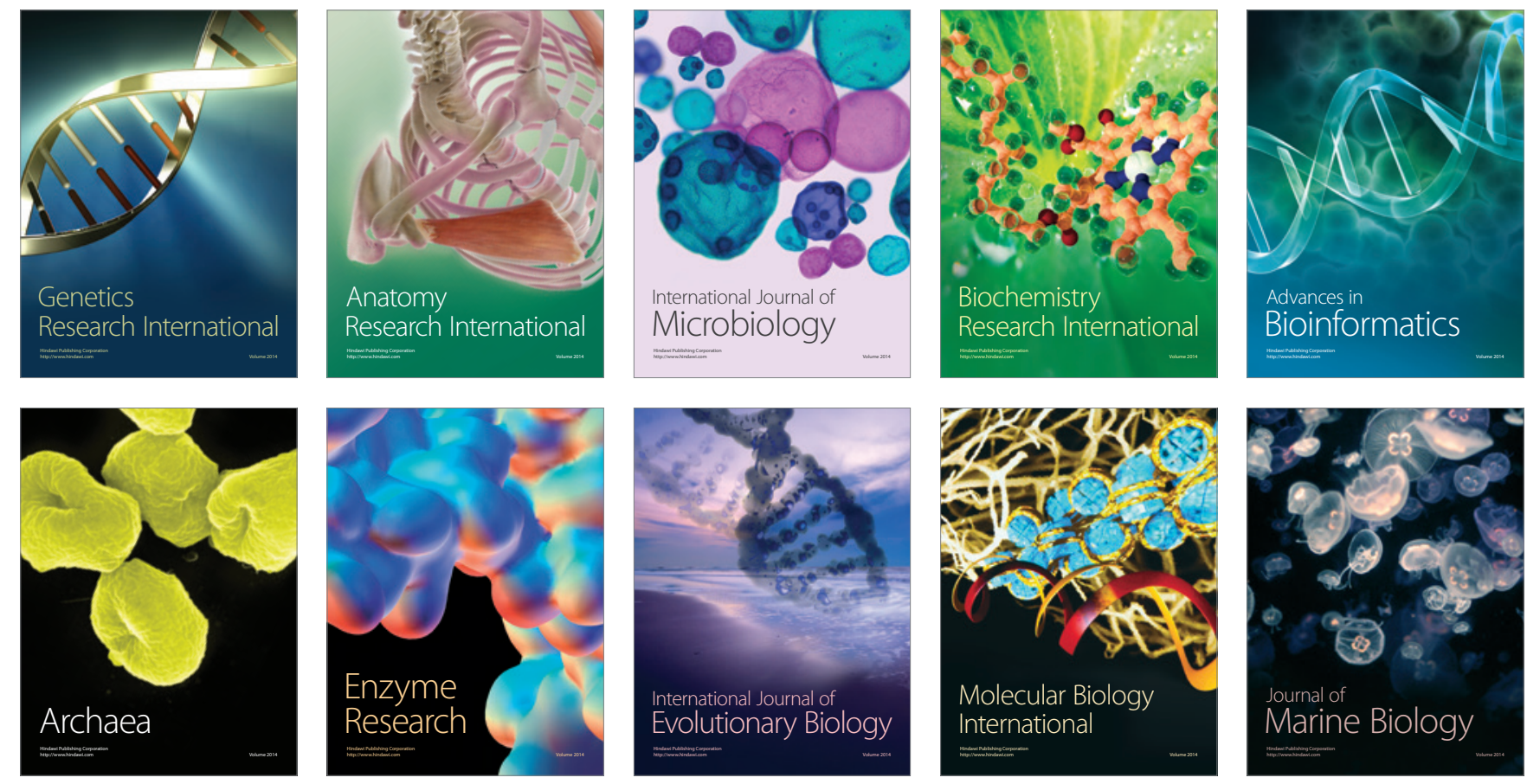